\title{
Het gebruik van geweld bij het bestraffen van overspel in Bijbelse teksten (Deuteronomium 22:13-29 en Johannes 7:53-8:11)
}

\author{
Wim J C Weren ${ }^{1}$ \\ Universiteit van Tilburg \\ Nederland
}

\begin{abstract}
The use of violence in punishing adultery in Biblical texts (Deuteronomy 22:13-29 and John 7:53-8:11)

In this article, the focus is on the extent to which in biblical texts violence is deemed acceptable in punishing adultery. Jesus' attitude to this severe punishment is discussed. Jesus concurs with the sanction imposed by Moses but the effect of his requirement that each individual in the group of executioners be without sin, is in fact that the punishment cannot be carried out. The way in which Jesus intervenes is in line of discussions in the Old Testament and in early Judaism that are aimed at imposing restraints of the use of violence in punishing sexual offences. The article concludes with an evaluation of the topical relevance or irrelevance of the two biblical pasages discussed here.
\end{abstract}

\section{INLEIDING}

In de Iraanse stad Takistan worden voorbereidingen getroffen voor de steniging van een man en een vrouw vanwege overspel, zo las ik op 21 juni 2007 in het dagblad Trouw. Al vanaf de geboorte van hun buitenechtelijke dochter, die inmiddels elf jaar is, heeft het tweetal in de gevangenis gezeten, in afwachting van hun veroordeling en executie. Nadat de zaak zich jarenlang

\footnotetext{
${ }^{1}$ Prof dr Wim J C Weren (Departement Religiewetenschappen en Theologie in de Faculteit Geesteswetenschappen, Universiteit van Tilburg, Nederland) zijn als gastonderzoeker betrokken by het hermeneutiek-project van prof dr Andries G van Aarde in de Afdeling Nieuw Testamentische Wetenschap van de Faculteit Theologie, Universiteit van Pretoria, in samenwerking met prof dr Pieter de Villiers (Universiteit van die Vrystaat).
} 
had voortgesleept, is nu eindelijk het vonnis geveld, en de rechter zal niet alleen bij de executie aanwezig zijn maar ook zelf de eerste steen werpen. Volgens betrouwbare bronnen is de mannelijke partner, Jafar Kihani, op 5 juli 2007 inderdaad geëxecuteerd, maar of de vrouw, Mokarrameh Ebrahimi geheten, nadien hetzelfde lot heeft ondergaan, is niet bekend. Het bericht over de voorgenomen executie leidde tot felle protesten. Steniging is een barbaarse straf die niet past in onze tijd, zo lieten krantenlezers in hun ingezonden brieven weten. Bij wijze van contrast wezen zij op de uitspraak van Jezus: "Wie van u zonder zonde is werpe de eerste steen." Door dit citaat in de strijd te werpen wekten zij de indruk dat het christendom een humanere religie is dan de islam.

Opmerkelijk is echter dat juist de Bijbel overspel bestraft wil zien met steniging (Deut 22:20-24; vgl Lev 20:10), terwijl de Koran een lichtere strafmaat voorschrijft voor dit vergrijp, namelijk honderd zweepslagen (Koran 24:2). Steniging als straf voor overspel komt niet voor in de Koran maar is wel te vinden in de traditieliteratuur (hadith) en is van daaruit opgenomen in de sharia, waar bepaald wordt dat deze wrede straf alleen kan worden opgelegd als aan een aantal voorwaarden is voldaan: er moeten vier mannelijke getuigen zijn, die betrouwbaar zijn; ze moeten het overspelige stel op heterdaad hebben betrapt (of beeldend uitgedrukt: ze moeten hebben gezien "dat de pen in het inktpotje werd gedoopt"), en hun verklaring moet eensluidend zijn (Abu-Zahra 2001:28-30; Frolov 2006:129-130). Deze voorwaarden zijn van dien aard dat het in de praktijk haast is uitgesloten dat steniging ooit als straf kan worden opgelegd.

De discussie over de executie in Takistan wekte mijn nieuwsgierigheid naar teksten uit de Bijbel waarin geweld wordt aangewend bij het bestraffen van overspel. Staat de strafmaat wel altijd in verhouding tot het vergrijp? Zijn er differentiaties in de op te leggen straf? Om deze vragen te beantwoorden stel ik een passage aan de orde waarin overspel aan de orde komt naast andere seksuele vergrijpen, namelijk Deuteronomium 22:13-29. Een tweede reden om dit fragment te bestuderen is dat juist deze tekst in het vizier is wanneer de schriftgeleerden en Farizeeën in Johannes 7:53-8:11 aan Jezus de vraag stellen wat hij denkt van de door Mozes verordende sanctie op overspel. Sluit Jezus zich aan bij Mozes, of formuleert hij een nieuwe visie op de aloude sanctie, en als dit laatste het geval is, in hoeverre kan hij dan aansluiten bij eerdere pogingen van anderen om het gebruik van geweld bij het afstraffen van seksuele vergrijpen in te dammen? Kunnen we de opstelling van Jezus verduidelijken aan de hand van wettelijke procedures die worden voorgeschreven in andere bijbelse teksten? 
Mijn artikel is als volgt opgebouwd. Ik start met een bespreking van de regels in Deuteronomium 22:13-29 met betrekking tot seksueel verkeer (paragraaf 2). Vervolgens stel ik aan de orde hoe het voorschrift van Mozes ten aanzien van de bestraffing van overspel in Johannes 7:53-8:11 wordt geïnterpreteerd en welke andere oudtestamentische teksten daarbij een rol spelen (paragraaf 3). Ik probeer de passage uit Johannes dus te verstaan tegen de achtergrond van andere bijbelse teksten. In deze semantische en intertekstuele analyse is mijn aandacht gericht op de mate waarin het gebruik van geweld toelaatbaar wordt geacht bij het afstraffen van seksuele vergrijpen (Weren 1999:89-109, 197-215). Ik sluit mijn bijdrage af met een evaluatie van de actuele relevantie of irrelevantie van de door mij besproken bijbelse teksten (paragraaf 4).

\section{REGELS IN DEUTERONOMIUM 22:13-29 MET BETREKKING TOT SEKSUEEL VERKEER}

Deuteronomium 22:13-29 is een tekstuele eenheid en bestaat uit zes bepalingen die betrekking hebben op seksueel verkeer (in deze paragraaf steun ik op Pressler 1993:21-43; 1994:102-112. Verder zij gewezen op Fuchs [2000], die boeiende beschouwingen wijdt aan de rol van de moeder, de bruid, de echtgenote, de dochter en de zuster in de Bijbel). Elke bepaling heeft de vorm van een casus, die in de Hebreeuwse tekst wordt ingeleid met

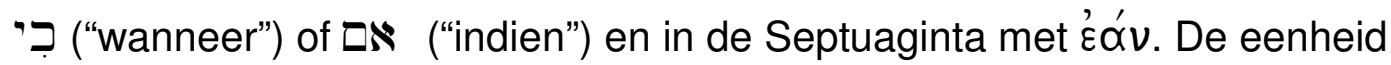
van de passage steunt verder op de volgende gegevens: enkele woorden worden twee of meer keren herhaald (bijv "man", "vrouw", "meisje", "gemeenschap hebben"); bij elk vergrijp wordt de daarbij behorende straf vermeld; de straf bestaat twee keer uit het betalen van een financiële vergoeding (Deut 22:19, 29), terwijl vier keer sprake is van de doodstraf (Deut $22: 21,22,24,25)$, die weer in twee gevallen nader wordt omschreven als steniging (Deut 22:21, 24); ten slotte zij gewezen op de als een refrein functionerende zuiveringsformule "zo zult u het kwaad uit uw midden (of: uit Israël) wegdoen" (Deut 22:21, 22, 24).

In de tekst is het doorgaans de man die het initiatief in handen heeft: hij uit de verdenking dat zijn vrouw al vóór het huwelijk seks heeft gehad met een ander; het is de man die een meisje ontmoet en haar vastgrijpt (קi in Deut 22:25 en תפשו in Deut 22:28); hij wordt betrapt terwijl hij gemeenschap met haar heeft en haar onteert (Deut 22:24, 29); bij wijze van straf wordt hem het recht ontzegd om een initiatief te nemen dat normaal gesproken bij hem ligt, namelijk zijn huwelijk te beëindigen en zijn vrouw te verstoten (Deut 22:19, 29). Anders dan de man is de vrouwelijke partner overwegend passief; zij is degene die de beschreven handelingen ondergaat; slechts enkele keren is zij 
het subject van een handeling: zij heeft een schanddaad gepleegd in Israël (Deut 22:21) en zij heeft al dan niet om hulp geroepen (Deut 22:24, 27).

In de eerste casus (Deut 22:13-19) en de daarbij behorende subcasus (Deut 22:20-21) gaat het over een getrouwde man, die er zijn bruid na de eerste huwelijksnacht van beschuldigt dat zij vóór het huwelijk seks heeft gehad met een ander en dus geen maagd meer was toen ze trouwde. In alle andere gevallen is de burgerlijke staat van de mannelijke partij niet duidelijk: hij kan gehuwd zijn maar evengoed kan hij nog vrijgezel zijn.

Dit is totaal anders in het geval van de vrouwelijke partner: haar burgerlijke staat wordt steeds nauwkeurig omschreven. In de tekst worden drie mogelijkheden genoemd:

- de vrouw is getrouwd (Deut 22:13-21, 22);

- het gaat om een meisje dat nog maagd is maar wel reeds is

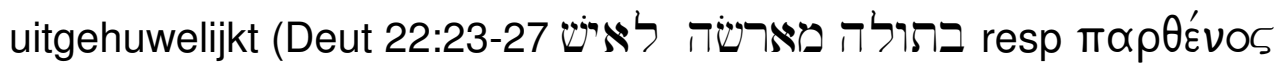
$\left.\mu \varepsilon \mu \nu \eta \sigma \tau \varepsilon \cup \mu \varepsilon^{\prime} \nu \alpha^{\alpha} v \delta \rho i\right)$;

- het gaat om een meisje dat maagd is en nog niet is uitgehuwelijkt (Deut

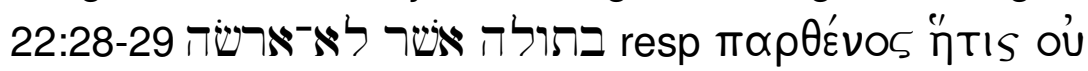

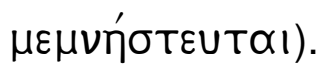

Voorts is van belang dat in de tekst twee duidelijk van elkaar onderscheiden situaties aan de orde komen. De eerste situatie is dat een meisje seks heeft (of gehad heeft) vóór haar huwelijk, de tweede situatie is dat zij als getrouwde of uitgehuwelijkte vrouw alsnog seksuele betrekkingen aanknoopt met een andere man dan haar eigen echtgenoot.

De eerstgenoemde situatie (seks vóór het huwelijk) is niet alleen aan de orde in de laatste casus (Deut 22:28-29) maar speelt ook - zij het vanuit een terugblikkend perspectief en zo niet als feit dan in ieder geval als mogelijkheid - een rol in de eerste casus en de daarbij behorende subcasus (Deut 22:13-21). Het verschil is dat het voorechtelijke geslachtsverkeer in Deuteronomium 22:28-29 ter plekke ontdekt wordt, op het moment van de daad zelf, terwijl er in Deuteronomium 22:13-21 sprake is van een verdenking die pas post factum (dat wil zeggen: nadat het meisje gehuwd is) geuit wordt door haar echtgenoot. Daarbij zijn er twee mogelijkheden: de beschuldiging is vals of steunt op de feiten. Als de beschuldiging ongegrond is, wordt de echtgenoot getuchtigd en moet hij aan de vader van het meisje een financiële compensatie geven voor de schande die hij de familie van het meisje heeft aangedaan door de roddel te verspreiden dat zijn vrouw geen maagd meer zou zijn geweest toen ze huwde. Bovendien moet de echtgenoot in dit geval het huwelijk, dat hij wilde beëindigen, gedurende heel zijn verdere leven in 
stand houden. Maar als de beschuldiging terecht is geuit wordt het meisje zwaar bestraft: ze wordt voor de ingang van het huis van haar vader gestenigd door de inwoners van de stad. Zij krijgt deze straf niet omdat ze zich schuldig zou hebben gemaakt aan overspel maar omdat ze ontucht heeft

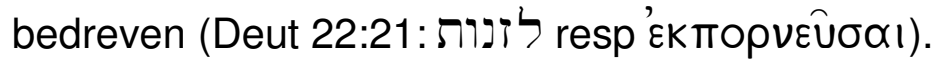

De in Deuteronomium 22:18-19 genoemde sancties lijken op de strafmaatregelen die getroffen worden in de laatste casus waarin er sprake van is dat een vrijend stel op heterdaad betrapt wordt. Dan moet de man, die het meisje overmeesterd heeft, aan de vader van het meisje een financiële vergoeding betalen en verder moet de dader trouwen met zijn slachtoffer en wordt hem het recht ontzegd om haar ooit nog te verstoten.

Dan nu de tweede situatie, seks met een andere man dan de eigen echtgenoot. Dit vergrijp komt zowel aan de orde in Deuteronomium 22:22 (waar sprake is van een getrouwde vrouw) als in Deuteronomium 22:23-27 (waar sprake is van een uitgehuwelijkt meisje dat nog maagd is). In de grond is de burgerlijke staat van de vrouwelijke partij in beide gevallen hetzelfde: immers, vanaf het moment waarop ze is uitgehuwelijkt valt zij onder het gezag van haar toekomstige echtgenoot; ook een uitgehuwelijkt meisje geldt als de vrouw van haar man (zie Deut 22:24: "de vrouw van zijn naaste").

Wanneer sprake is van seksueel verkeer van een getrouwde vrouw met een andere man dan haar echtgenoot, moeten ze allebei ter dood gebracht worden; op welke wijze dat dient te gebeuren, wordt in Deuteronomium 22:22 niet geëxpliciteerd. In het geval van een maagd die al is uitgehuwelijkt, wordt rekening gehouden met de vraag of het meisje wel of niet om hulp heeft geroepen. Daaruit moet blijken of ze wel of niet instemde met het hebben van seksuele omgang met een vreemde man. Volgens de tekst is het van belang of het vergrijp plaatsvindt in de stad, waar haar hulpgeroep kan worden gehoord, dan wel in het vrije veld waar niemand haar te hulp kan schieten. Als het meisje zich niet heeft verzet wordt zij samen met haar sekspartner gestenigd; als ze zich wel heeft verzet wordt alleen de man die haar tegen haar wil heeft overmeesterd, om het leven gebracht.

De straf is dus niet altijd hetzelfde; de strafmaat is afhankelijk van twee variabelen: de status van de vrouwelijke partij en de vraag of zij al dan niet heeft ingestemd met het hebben van seks (Pressler 1994:106; volgens Westbrook [1992] zijn deze variabelen ook te vinden in wetscodices uit de Umwelt van Israël). Door de tweede variabele in het geding te brengen worden overspel en verkrachting van elkaar afgegrensd. Niet alle seksuele vergrijpen die in deze tekst genoemd worden, worden bestraft met de dood; voor bepaalde vergrijpen is een financiële vergoeding afdoende. De tekst bevat geen aanwijzing voor het idee dat de doodstraf vervangen zou kunnen 
worden door een alternatieve straf, zoals het publiekelijk ontkleden van een overspelige vrouw (Jer 13:22-27; Ez 16:37, 39; 23:26, 29; Hos 2:5,12) of het verminken van haar gezicht door haar de neus of de oren af te snijden (Ez 23:25).

De regelgeving betreffende seksueel verkeer wordt bewaakt door de gehele gemeenschap en wordt niet overgelaten aan individuen. Aanklachten moeten worden ingediend bij de oudsten van de stad, die vervolgens beoordelen of ze gegrond zijn. De executie door steniging wordt uitgevoerd door een collectieve beul: de mannen van de stad (Deut 22:21, 24). Ook de formule "zo zult u het kwaad uit Israël wegdoen" geeft aan dat seksuele vergrijpen geen privé-aangelegenheid zijn maar de gehele gemeenschap ontregelen en verontreinigen.

Deuteronomium 22:13-19 bevat een waarschuwing aan het adres van de echtgenoot om zijn partner niet valselijk te beschuldigen van seksueel verkeer met een ander in de periode vóór het huwelijk. Door het afleggen van een vals getuigenis voor de oudsten zou de echtgenoot het risico lopen dat hij zelf wordt aangeklaagd en de straf krijgt opgelegd die hij zijn partner had toebedacht (vgl Deut 19:16-19; zie Pressler 1993:24, 42). Deuteronomium stelt hier hogere eisen aan de echtgenoot dan de passage over de proef met het bittere water (Num 5:11-31). Volgens de tekst uit Numeri gaat de man die zijn vrouw wantrouwt en haar in een vlaag van jaloezie aan de proef met het bittere water laat onderwerpen, ook vrijuit als de proef uitwijst dat de verdenking van overspel ongegrond is.

Ter afsluiting van deze paragraaf stel ik vast dat Deuteronomium 22:13-29 vooral gericht is op het reguleren van de seksualiteit van vrouwen en dat de vrouwelijke seksualiteit hier onder de zeggenschap valt van mannen (of nog scherper: "female sexuality is male property" [Pressler 1994:112]). Dit geldt zowel voor ongehuwde meisjes, die onder het gezag vallen van hun vader, als voor uitgehuwelijkte en getrouwde vrouwen, die zich te voegen hebben naar hun (toekomstige) echtgenoot.

Ik licht deze bewering in het kort toe en begin met de situatie van het jonge, ongehuwde meisje. Haar maagdelijkheid wordt bewaakt door haar vader. Als zij het slachtoffer wordt van verkrachting, is dat primair een belediging voor haar vader en ook een financiële schadepost want hij kan haar in die situatie minder gemakkelijk tegen een goede prijs uithuwelijken. Indien de dader wordt betrapt, dan moet hij aan de vader van het meisje een schadevergoeding betalen en het meisje voor de rest van zijn leven tot vrouw nemen. Dit gedwongen huwelijk wordt door de bijbelse auteur gezien als een oplossing die aan het meisje de nodige bestaanszekerheid geeft en voor haar vader voldoende eervol is. 
De zwaarste sanctie, de doodstraf, staat op overspel of echtbreuk. In de Bijbel valt hier iedere vorm van vrijwillig seksueel verkeer onder van een getrouwde of uitgehuwelijkte vrouw met een andere man dan haar eigen echtgenoot (Goodfriend 1992). Seksuele omgang van een gehuwde man met een ongetrouwde vrouw wordt niet als echtbreuk beschouwd maar als ontucht. Het huwelijk dat door overspel verbroken wordt, is de verbintenis tussen de vrouw en de man met wie zij gehuwd is, en niet de verbintenis tussen de overspelige man en zijn echtgenote. Deze definitie laat zien dat overspel primair een aantasting is van het exclusieve recht van de echtgenoot op seksueel verkeer met zijn partner. Seksuele omgang van een derde met een uitgehuwelijkte of getrouwde vrouw wordt beschouwd als een aantasting van de eer van haar (toekomstige) echtgenoot; zijn eer is ten nauwste verbonden met haar kuisheid. Waarom geldt voor vrouwen een strengere seksuele ethiek dan voor mannen? Dat komt omdat mannen er zeker van willen zijn dat de kinderen die hun vrouwen baren, van henzelf zijn, dat deze kinderen werkelijk tot de familie behoren en geen bastaarden zijn. De zuiverheid die hier betracht wordt is van belang voor het eigendoms- en het erfrecht.

We vinden de hier geschetste opvattingen terug in Deuteronomium 22:22-27: op overspel staat de doodstraf; de man wordt gedood omdat hij zich inlaat met de vrouw van een ander en zo ook de gehele gemeenschap ontwricht; de vrouw wordt alleen gedood als zij zich vrijwillig in het buitenechtelijk avontuur heeft gestort. Welke concrete procesgang er nodig is om te waarborgen dat het uitspreken van een doodvonnis vrij is van willekeur, wordt in deze passage niet uitgewerkt, maar komt - zoals we nog zullen zien - elders in de thora aan de orde.

\section{EEN SEMANTISCHE EN INTERTEKSTUELE ANALYSE VAN JOHANNES 7:53-8:11}

In deze paragraaf bespreek ik de houding van Jezus tegenover de door Mozes voorgeschreven sanctie. Alvorens Johannes 7:53-8:11 te belichten vanuit zijn intertekstuele relaties met oudtestamentische teksten, ga ik eerst in het kader van een intratekstuele analyse in op patronen en betekenislijnen die zich binnen dit verhaal aftekenen. Dit laatste wordt echter bemoeilijkt door de tekstkritische problemen waarmee Johannes 7:53-8:11 omgeven is.

\subsection{Tekstkritische problemen}

Hoe de oorspronkelijke Griekse tekst van Johannes 7:53-8:11 geluid heeft, is onzeker: binnen het bestek van 183 woorden treffen we hier maar liefst 80 tekstvarianten aan (aldus Rius-Camps 2007:383, onder verwijzing naar een 
studie van Willker). Dit hoge aantal hangt samen met de complexe tekst- en overleveringsgeschiedenis van het verhaal. Naar het oordeel van bijna alle tekstcritici is de plaatsing van het verhaal in de huidige literaire context secundair en heeft deze perikoop oorspronkelijk niet tot het vierde evangelie behoord. Daarvoor worden door Metzger (1975:219-222) drie argumenten aangevoerd: a) de passage ontbreekt in vele oude en kwalitatief goede Griekse handschriften en oude vertalingen; $b$ ) de taal en stijl van Johannes 7:53-8:11 wijken af van die van de rest van het vierde evangelie; c) deze passage verstoort de aansluiting van Johannes 8:12 bij 7:52. Van Houwelingen (2007:428-429) kiest voor een alternatieve oplossing: het verhaal behoorde wel tot de oorspronkelijke tekst van het vierde evangelie maar is in een vroeg stadium uit een deel van de handschriftentraditie verwijderd.

Het eerste argument steunt op de zogenaamde external textual evidence en legt veel gewicht in de schaal. De twee andere argumenten zijn minder overtuigend. Weliswaar bevat de tekst termen die eerder tot het synoptische dan tot johanneïsche vocabulaire behoren, maar daar staat tegenover dat er verschillende linguïstische verbanden zijn tussen het verhaal over de van overspel beschuldigde vrouw en de rest van Johannes.

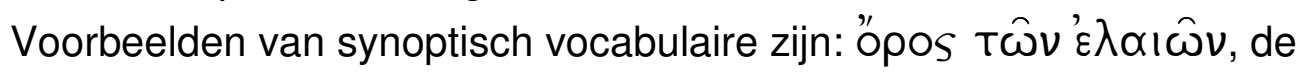
tijdsaanduiding o $\rho \theta \rho o u$, de zittende houding van Jezus tijdens zijn onderricht, het optreden van de schriftgeleerden en het syntagma ó $\gamma p \propto \mu \mu \alpha \tau \varepsilon \hat{~}$ oi Фapıơ̂ioı.

Heil (1991) wijst erop dat Johannes 8:2 ten dele dezelfde woorden bevat als Johannes 7:14, en vestigt de aandacht op overeenkomsten tussen Johannes 8:6 en 6:6, tussen 8:7 en 8:59 en tussen 8:11 en 5:14. Verder meent hij dat de perikoop bijdraagt aan de narratieve voortgang in Johannes 7-8. Dit laatste wordt ook verdedigd door Kim (2004:120-124).

Dat Johannes 8:12 perfect zou aansluiten bij 7:52 is betwistbaar, want dan zouden de met $\pi \alpha^{\prime} \lambda ı$ I...] đưTôs ' $\varepsilon \lambda \alpha^{\prime} \lambda \eta \sigma \varepsilon v$ ingeleide woorden van Jezus in Johannes 8:12 gericht moeten zijn tot de hogepriesters en de Farizeeën die in Johannes 7:45-52 in vergadering bijeen zijn; het ligt meer voor de hand om aútốs uit 8:12 te betrekken op "heel het volk" in Johannes 8:2 (vgl aưtoús in datzelfde vers).

De vrij algemeen gangbare opvatting omtrent het secundaire karakter van de huidige plaatsing van het verhaal in Johannes gaat hand in hand met het haast even algemeen verbreide idee dat we hier te maken hebben met een oud verhaal dat al vroeg circuleerde in de mondelinge traditie. Dat verhaal zou aanvankelijk uit de evangeliën geweerd zijn vanwege de al te 
tolerante houding van Jezus ten opzichte van overspel. Later zou het door een aantal handschriften op uiteenlopende plaatsen in de evangeliën zijn ingevoegd: niet alleen in aansluiting op Johannes 7:52 (zoals in D, enkele oude Latijnse handschriften, de Vulgata en vele late Griekse minuskels) maar ook na Johannes 7:36 of 7:44 of 21:25 of na Lucas 21:38 of 24:53 (zie Becker 1963; Lührmann 1990; Rius-Camps 2007). Volgens Ehrman (1988:37) circuleerden er tegen de vierde eeuw drie versies van het verhaal:

(1) the entrapment story in which Jesus freely pardons a sinful woman, known to Papias and the author of the Didascalia,

(2) the story of Jesus' intervention in an execution proceeding, preserved in the Gospel according to the Hebrews and retold by Didymus in his Ecclesiastes commentary, and

(3) the popular version found in MSS of the Gospel of John, a version which represents a conflation of the two earlier stories.

De onzekerheid omtrent de Griekse tekst en de oorspronkelijke literaire setting van Johannes 7:53-8:11 bemoeilijkt het uitvoeren van een semantische en intertekstuele analyse. Wat betreft de Griekse tekst waarvan ik in mijn analyse uitga, kan ik me veilig baseren op de reconstructie die we aantreffen in de $27^{\text {ste }}$ editie van Nestle-Aland. Lastiger is het dat de oorspronkelijke literaire context van het verhaal onbekend is en dat de inbedding in Johannes 7:14-8:59 secundair is. Dit vermindert de mogelijkheden om de betekenis en de functie van het verhaal vast te stellen. Het normale principe dat de betekenis van een perikoop mede wordt bepaald door de omringende teksten, kan in dit geval minder trefzeker worden toegepast.

\subsection{Patronen en betekenislijnen in Johannes 7:53-8:11}

Ondanks deze beperkingen kunnen we wijzen op enkele patronen en betekenislijnen die van belang zijn voor een goed verstaan van het verhaal. Johannes 7:53-8:11 heeft een heldere opbouw; het verhaal bestaat uit drie onderdelen: ${ }^{2}$
A $\quad 7: 53-8: 2$
B $\quad 8: 3-9$
B' $\quad 8: 10-11$

inleidende situatieschets eerste gespreksronde: Jezus en de aanklagers tweede gespreksronde: Jezus en de aangeklaagde vrouw

\footnotetext{
${ }^{2}$ Rousseau (1978:463-480) stelt de volgende indeling voor: inleiding (Joh 7:53-8:2); het daarop volgende verhaal bestaat volgens hem uit drie onderdelen: A (de kwestie: Joh 8:3-6a), B (eerste reactie: Joh 8:6b-7), B' (tweede reactie: Joh 8:8-11).
} 
In de inleiding wordt verteld dat iedereen naar huis gaat. Hiermee zijn in de huidige literaire context de gerechtdienaren en de hogepriesters en Farizeeën bedoeld, die elkaar in Johannes 7:45-52 ontmoet hebben. Jezus vertrekt naar de Olijfberg maar in de vroegte begeeft hij zich weer naar de tempel, waar hij omstuwd wordt door heel het volk dat door hem onderricht wordt. Deze inleidende verzen zijn slechts losjes verbonden met het daarop volgende verhaal over een van overspel betichte vrouw.

Tamelijk abrupt verschijnen in B nieuwe personages op het toneel: de schriftgeleerden en de Farizeeën, die een vrouw met zich meevoeren en haar beschuldigen van overspel. In Johannes 8:9 druipen ze een voor een af, terwijl ze de vrouw achterlaten op de plaats waar ze haar hadden neergezet (zie ' $\varepsilon \nu \mu \varepsilon^{\prime} \sigma \omega$ in Joh 8:3, 9). In Johannes 8:5 stellen de aanklagers een vraag aan Jezus, waarop hij pas in Johannes 8:7 een reactie geeft; het antwoord van Jezus staat ingeklemd tussen de tweevoudige vermelding dat hij zich bukt en op de grond schrijft. Wanneer Jezus zich in B' voor de tweede keer opricht is hij alleen met de vrouw. Dan is hij het die vragen stelt. Nadat de vrouw bevestigd heeft dat zij door niemand is veroordeeld, laat Jezus haar gaan met de opdracht om niet meer te zondigen (vgl Joh 5:14).

De tekst heeft de vorm van een juridisch dispuut. Dit valt af te leiden uit het verschijnsel dat de onderdelen B en B' gekenmerkt worden door het frequente gebruik van juridische taal: volgens de verteller is de vrouw op overspel betrapt (Joh 8:3), en hetzelfde horen we uit de mond van de schriftgeleerden en Farizeeën: "deze vrouw is op heterdaad betrapt toen ze overspel pleegde" (Joh 8:4). In een commentaarzin laat de verteller weten dat de aanklagers van de vrouw er eigenlijk op uit zijn om een aanklacht tegen

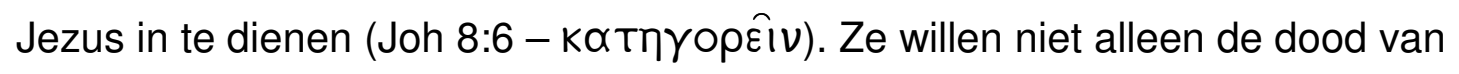
de vrouw maar ook van Jezus, die ze evengoed verdenken van ontrouw aan de thora. Hoewel de man met wie de vrouw het bed heeft gedeeld, in geen velden of wegen te bekennen is, zijn er in het verhaal dus toch "two lawbreakers, two border-crossers who are judged equally" (Guardiola-Sáenz 2000:280). Juridische taal komt ook voor in Johannes 8:7 waar sprake is van de uitvoering van het vonnis (de eerste steen werpen), en in 8:10-11 waar de vrouw beweert dat niemand haar veroordeeld heeft, waarop Jezus haar laat weten dat zelfs hij haar niet veroordeelt.

Door de commentaarzin in Johannes 8:6 waarin de verteller de lezer informeert over de dubieuze motieven van de aanklagers, krijgt het gehele verhaal iets dubbels. De vrouw is slechts een pion in een schaakspel, ze wordt ingezet om Jezus in de val te laten lopen. De opponenten willen weten of Jezus zich houdt aan de voorschriften van Mozes; met nadruk vragen ze wat Jezus vindt van steniging als de door Mozes verordonneerde sanctie op 
overspel: "Wat vindt u daarvan?" (бú staat voorop). De vraag is niet of Jezus de voorkeur geeft aan een andere vorm van doodstraf dan steniging, zoals verbranding (Gen 38:24; Lev 20:14; 21:19), onthoofding (Ex 32:27) en wurging of ophanging (2 Sam 21:6, 9; b Sanh 52b); nee, ze willen weten of de doodstraf ook volgens hem een gepaste sanctie is op overspel. "The question put to Jesus was not ... whether or not the woman was liable to be stoned as contrasted with some other penalty, but whether, in view of Moses' provision, she could lawfully in the circumstances be stoned" (Derrett 1970:174). Dat ze deze vraag stellen, doet vermoeden dat deze kwestie ter discussie stond en dat een mildere sanctie ook wel verdedigd werd.

\subsection{Herkomst van de aanhaling in Johannes 8:5}

De vermelding van de wet van Mozes in Johannes 8:5 functioneert als een signaal dat er woorden uit het Oude Testament in stelling worden gebracht. Toch volgt er geen expliciet citaat. De schriftgeleerden en Farizeeën geven de door hen bedoelde regel in hun eigen woorden weer: "In de wet heeft Mozes ons opgedragen zulke vrouwen te stenigen." Deze vrije formulering maakt het niet eenvoudig om precies te bepalen welke Schriftplaats zij op het oog hebben. Er zijn twee mogelijkheden: Leviticus 20:10 en Deuteronomium 22:22. Beide teksten verordonneren de doodstraf voor overspel, zowel voor de man als voor de vrouw. In Leviticus 20:10 wordt zowel in de Hebreeuwse tekst als in de Septuaginta bepaald dat een man die seks heeft met de vrouw van een ander, ter dood moet worden gebracht, samen met zijn sekspartner, maar op welke wijze dat moet gebeuren, wordt niet gespecificeerd.

De andere mogelijkheid is dat de gesprekspartners van Jezus in Johannes 8:5 een toespeling maken op Deuteronomium 22:22. Ook in dit geval volgt de Septuaginta de Hebreeuwse tekst op de voet. Inhoudelijk gezien komt Deuteronomium 22:22 overeen met Leviticus 20:10: ook hier gaat het over overspel van een man met een getrouwde vrouw en ook hier wordt dat vergrijp bestraft met de dood. In geen van beide teksten uit de thora is sprake van "stenigen", terwijl daarvan wel sprake is in Johannes 8:5 $\left(\lambda_{1} \theta \alpha \alpha^{\prime} \zeta \omega\right)$ en in 8:7 ( $\left.\beta \alpha^{\prime} \lambda \lambda \omega \lambda \lambda^{\prime} \theta \circ v\right)$. Deze term komt evenwel ook voor in de directe context van Deuteronomium 22:22, namelijk in 22:21 en 22:24. De Hebreeuwse tekst (באבנים + סקל) is in de LXX op een semitiserende wijze weergegeven ( $\lambda_{1} \theta \circ \beta \circ \lambda \varepsilon^{\prime} \omega$ ' $\varepsilon \nu \lambda_{1}^{\prime} \theta$ ols). Het in Johannes 5:8 gebruikte $\lambda_{ı} \theta \alpha{ }^{\prime} \zeta \omega$ komt in de Septuaginta voor in 2 Samuël 16:6, 13, waar Simeï stenen naar David werpt.

$\mathrm{Er}$ is nog een element in het verhaal uit Johannes dat misschien teruggaat op de bepalingen over overspel in Deuteronomium. Ik doel op het gegeven dat zowel de verteller als de aanklagers in Johannes 8:3-4 naar 
voren brengen dat de vrouw op heterdaad betrapt is. Wellicht is dit een allusie op Deuteronomium 22:22 waar van de man gezegd wordt dat hij betrapt wordt. De intertekstuele relatie is echter tamelijk zwak, want het vocabulaire is totaal anders: in Johannes treffen we de combinatie aan van $k \alpha \tau \propto \lambda \propto \mu \beta \alpha^{\prime} \nu \omega$

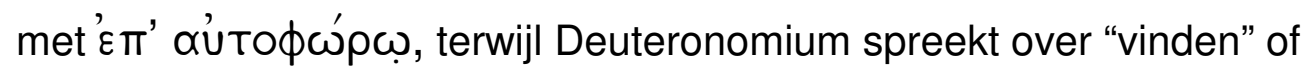

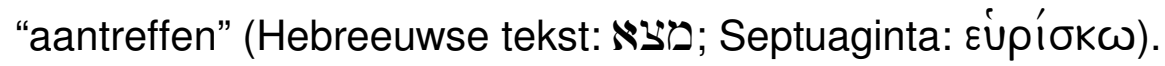

Uit deze beschouwingen valt te concluderen dat Johannes 7:53-8:11 duidelijkere connecties heeft met Deuteronomium 22:22 (bezien binnen zijn literaire context) dan met Leviticus 20:10.

\subsection{De interpretatie van het voorschrift van Mozes in Johannes 7:53-} 8:11

De vraag is nu hoe de regels over overspel uit Deuteronomium 22:22-27 in Johannes 7:53-8:11 geïnterpreteerd worden. Zoals we zagen verordonneert Deuteronomium 22:22 de doodstraf voor overspel, zowel voor de man als voor de vrouw. De schriftgeleerden en Farizeeën geven deze bepaling uit de wet van Mozes als volgt weer: "Mozes heeft ons in de wet opgedragen zulke vrouwen te stenigen." Technisch gezien stoten we hier op een voorbeeld van een verdraaiing, dat wil zeggen op "het al dan niet vrijwillig verkeerd interpreteren van een grondtekst" (Claes 1988:56). Zij verdraaien de bepaling uit de thora door een generaliserende uitspraak te doen over "zulke vrouwen" en door de beschuldigende vinger alleen te richten op de vrouw en met geen woord te reppen over haar mannelijke sekspartner. Let in dit verband op de

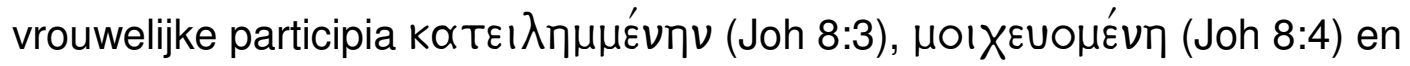
op tàs Toı aútas (Joh 8:5). Hoe dit te rijmen valt met het gegeven dat het stel op heterdaad is betrapt, blijft duister. ${ }^{3}$

Verder valt op dat de in algemene termen omschreven straf uit Deuteronomium 22:22 ("ter dood brengen") in Joh 8:5 gespecificeerd wordt tot "stenigen." Wat is de betekenis en functie van deze substitutie? Sommige exegeten denken dat we uit de keuze voor de term "stenigen" moeten afleiden dat de van overspel beschuldigde vrouw geen getrouwde vrouw is (zoals in Deut 22:22) maar een jong meisje dat al is uitgehuwelijkt (volgens Deut 22:2324 moet zo'n meisje gestenigd worden als ze seksuele omgang heeft gehad met een vreemde man).

Ik betwijfel ten zeerste of de verteller deze fijne nuances op het oog heeft gehad. Er is naar mijn oordeel een betere verklaring voor het gegeven dat hij opteert voor "stenigen" en niet voor de meer algemene term "ter dood

\footnotetext{
${ }^{3}$ Joh 7:53-8:11 bevat nog andere bevreemdende elementen. Een vrij complete inventarisatie van dergelijke elementen is te vinden in Watson (1999:100-108).
} 
brengen." Deze verklaring is dat stenigen een straf is die wordt uitgevoerd door een collectieve beul, zodat niet precies duidelijk is wie de dood van de geëxecuteerde veroorzaakt (dezelfde situatie als bij een vuurpeloton). In zijn antwoord op de vraag of zulke vrouwen moeten worden gestenigd, decollectiviseert Jezus de groep die op het punt staat de doodstraf uit te voeren. Hij doet dat door ieder individu uit dat collectivum aan te spreken op zijn

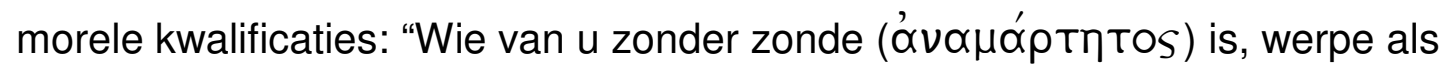
eerste een steen naar haar." Het effect van deze uitspraak is dat ze een voor een afdruipen en dat er niemand meer overblijt om de steniging te voltrekken.

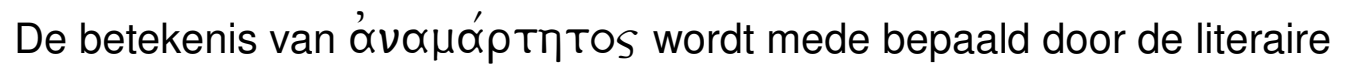
context. In Johannes 8:7 betekent "zonder zonde zijn" dat men zuivere motieven heeft bij het aanklagen van de vrouw. De verteller heeft al in Johannes 8:6a aan de lezers laten weten dat dit niet het geval is.

Is Jezus nu ontrouw aan de wet van Mozes? Nee, hij handhaaft de door Mozes bevolen sanctie (steniging) maar door aan elk individu uit de groep van executeurs de eis te stellen dat hij zonder zonde is, bewerkt hij in feite dat de straf niet kan worden uitgevoerd.

\subsection{Andere oudtestamentische teksten}

Johannes 7:53-8:11 bevat nog andere allusies op oudtestamentische teksten, die de daarnet getrokken conclusie nog versterken.

Volgens de verteller en haar aanklagers is de vrouw op heterdaad betrapt (Joh 8:3, 4). De hier gebezigde Griekse uitdrukking ( $\alpha \tau \alpha \lambda \alpha^{\prime} \mu \beta \propto \nu \omega$

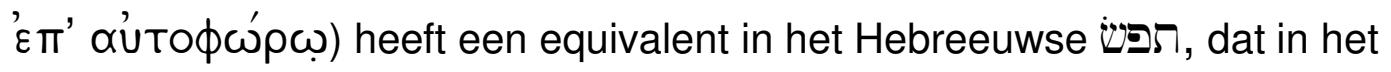
Oude Testament alleen in Numeri 5:13 voorkomt in verband met seksueel

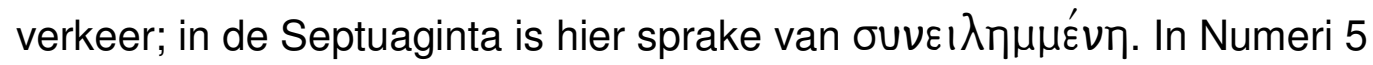
onderwerpt een echtgenoot die zijn vrouw verdenkt van overspel ofschoon niemand haar en haar minnaar betrapt heeft, aan de proef met het bittere water. In Johannes speelt deze proef geen rol. Hier wordt door niemand betwijfeld of de vrouw wel overspel heeft gepleegd; ook Jezus is ervan overtuigd dat de vrouw gezondigd heeft (Joh 8:11 "zondig vanaf nu niet meer"). Een probleem is echter dat niet duidelijk is wie de vrouw betrapt heeft, en al evenmin met wie ze zich in een compromitterende situatie heeft bevonden.

Volgens Deuteronomium 17:6-7 en 19:15 is voor de veroordeling tot de doodstraf een verklaring nodig van ten minste twee getuigen en kan de executie niet worden uitgevoerd op de verklaring van één getuige. Bovendien wordt daar bepaald dat de getuigen het voortouw moeten nemen bij de uitvoering van het vonnis. Een allusie hierop is te vinden in de uitspraak van 
Jezus over wie als eerste een steen mag werpen. Dat hij binnen de amorfe groep van potentiële uitvoerders van de doodstraf een hiërarchie aanbrengt, ligt in de lijn van de bepaling in Deuteronomium 17:6-7. Dat hij daarbij een beroep doet op hun morele kwalificatie, heeft eveneens wortels in het Oude Testament, waar veel nadruk wordt gelegd op de integriteit van de getuigen en waar valse getuigen met strafmaatregelen worden afgeschrikt (Ex 23:1-3, 6-8; Deut 19:16-19; zie het verhaal over Suzanna in Dan 13). Volgens b Sotah $47 \mathrm{~b}$ geeft de test met het bittere water alleen een betrouwbaar resultaat als de echtgenoot vrij is van schuld. Deze interpretatie komt overeen met Jezus' uitspraak in Johannes 8:7.

Uit deze gegevens vallen twee conclusies te trekken. De eerste is dat reeds in het Oude Testament de doodstraf gezien wordt als het eindpunt van een procesgang die aan zo'n strikte regels is gebonden dat de straf in de praktijk niet vaak wordt voltrokken. Dit geldt ook voor gevallen van overspel. De tweede conclusie is dat het allerminst duidelijk is dat deze strikte regels in het verhaal uit Johannes allemaal in acht worden genomen. Zijn er wel (oog)getuigen? Is hun verklaring eensluidend en afdoende? Is de vrouw al voor een rechtbank gebracht en ter dood veroordeeld? Hebben de aanklagers wel zuivere bedoelingen? Het verhaal bevat vele lacunes waar het de precieze procesgang betreft. Jezus zou de voorschriften uit de thora die een zuivere procesgang willen waarborgen, met voeten hebben getreden als hij bij zoveel juridische onduidelijkheid de executie van de vrouw niet zou proberen tegen te houden. Hij doet dat door één belangrijke kwestie aan de orde te stellen: de integriteit van de aanklagers respectievelijk van degenen die de steniging zullen gaan uitvoeren. De wijze waarop Jezus intervenieert, ligt in de lijn van discussies in het Oude Testament en in het vroege jodendom over de eisen die gesteld moeten worden aan een behoorlijke procesgang (Derrett 1975; James 1979; Aus 1998:1-49; Holmes \& Holmes Winfield 2003:143162).

Het aantal verwijzingen naar oudtestamentische teksten groeit nog wanneer we aannemen dat Jezus woorden uit dergelijke teksten op de grond schrijft. Over wat hij neerschrijft wordt in de tekst met geen woord gerept. Dat maakt onderzoekers juist extra nieuwsgierig en ze hebben de meest ingenieuze voorstellen gedaan, waarvan ik er een paar noem. Reeds kerkvaders als Ambrosius, Augustinus en Hieronymus hebben gewezen op Jeremia 17:13 omdat in deze tekst gezegd wordt dat de afvalligen, die zich verwijderen van Israëls God, "in de aarde geschreven zullen worden"

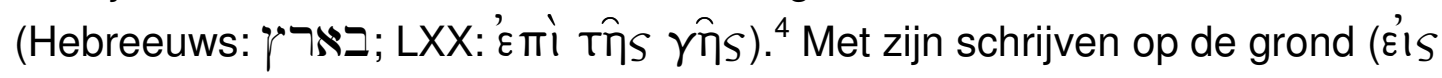

\footnotetext{
${ }^{4}$ Een uitvoerige studie over de relatie tussen Johannes 8:6-8 en Jeremia 17:13 is Schwarz (1982:239-256).
} 
Tív $\gamma \hat{\eta} v$ ) herinnert Jezus aan de in Jeremia genoemde handeling. Het gebaar alleen al houdt een hard oordeel in over de omstanders: als afvalligen zijn zij - in religieuze zin - de ware echtbrekers, terwijl de vrouw niet veroordeeld wordt en kan rekenen op Gods barmhartigheid.

Vermeldenswaardig is ook de oplossing van Derrett (1975:175-186). Volgens hem schrijft Jezus alleen de (welgeteld zestien!) beginletters in het zand uit twee bijbelverzen, namelijk eerst Exodus 23:1b ("Maak geen gemene zaak met een misdadiger ....) en vervolgens Exodus 23:7a ("Van een bedrieglijke zaak moet u zich ver houden ..."). Met deze verzen herinnert Jezus de schriftgeleerden en de Farizeeën eraan dat hun zaak niet spoort met de thora. Dat Derrett juist deze teksten kiest, hangt samen met het door hem verdedigde idee dat de echtgenoot van de vrouw, die zich van haar wil ontdoen, de hele zaak heeft geënsceneerd en daarbij valse getuigen heeft ingeschakeld.

Nog ingewikkelder is het voorstel van Aus (1998:26-34), die in het geval van Johannes 8:6 denkt aan Maleachi 2:11, waar Juda wordt gehekeld vanwege zijn huwelijk met een heidense vrouw, en in het geval van Johannes 8:8 aan Hosea 4:14, waar God verzekert dat hij Israëls dochters niet zal straffen voor hun ontucht, met als suggestie dat dan ook mensen zware sancties achterwege moeten laten. Ook bij Aus sporen de gekozen teksten met de interpretatie die hij geeft van de totale passage: hij verdedigt dat de vrouw, een Jodin, een affaire heeft gehad met een Romein, een niet-Jood, die niet onder de thora valt maar onder het - veel mildere - Romeinse strafrecht, en daarom hier ook niet gedaagd kan worden.

Hoe moeten we deze voorstellen beoordelen? De juistheid ervan kan niet worden bewezen omdat ze informatie verschaffen over iets waarover de tekst zelf zwijgt, namelijk over de (aan de Schrift ontleende) woorden die Jezus op de grond geschreven zou hebben. Een tekstueel feit is wel dat Jezus op de grond schrijft. Dit gebaar kan worden omschreven als een Gleichnishandlung, een symbolische act waarvan binnen de concrete situatie een bepaalde boodschap uitgaat, die misschien nader kan worden aangeduid vanuit oudtestamentische teksten waarin sprake is van de vinger Gods die de stenen tafelen beschrijft (Ex 31:18; Deut 9:10) of van vingers van een mensenhand die een soort rebus op de muur schrijven van het paleis van koning Belsassar (Dan 5:5,24). In het eerste geval gaat het om de oorsprong van de schriftelijke thora, waarvan de geldigheid de inzet is van de discussie in ons verhaal. Zou het schrijven van Jezus op de grond binnen dat kader niet kunnen beduiden dat latere generaties voortdurend verder moeten schrijven aan de thora, in het licht van telkens wisselende situaties? Of moeten we het schrijven van Jezus verbinden met de vingers uit Daniël 5 die een strafoordeel neerschrijven over koning Belsassar in Daniël 5? 


\subsection{Resultaat}

Het resultaat van deze semantische en intertekstuele analyse van Johannes 7:53-8:11 kan nu als volgt worden weergegeven. Jezus sluit zich in het juridische dispuut met de schriftgeleerden en Farizeeën over de toepasbaarheid van steniging in het geval van overspel aan bij de in de thora genoemde sanctie, maar tevens legt hij er de vinger op dat andere bepalingen uit de wet van Mozes moeten worden nageleefd die een zorgvuldige procesgang willen waarborgen. Met zijn opstelling sluit Jezus zich aan bij een reeds in het Oude Testament begonnen traditie, die we goed geïllustreerd vinden in het verhaal over Suzanna. Binnen het pluriforme jodendom in de eerste eeuw van onze jaartelling is de aan Jezus toegeschreven opstelling geen unicum. Wellicht zijn discussies binnen het contemporaine jodendom over het afstraffen van overspel mede beïnvloed zijn door de veranderingen in de Romeinse wetgeving zoals we die bijvoorbeeld kennen uit de door Augustus in 18 voor het begin van onze jaartelling uitgevaardigde Lex lulia. Derrett (1975:168) is pertinent in zijn oordeel: "No Roman judge would condemn to death a woman taken in adultery."

\section{ACTUELE (IR)RELEVANTIE VAN BIJBELSE TEKSTEN OVER OVERSPEL}

Aan het begin van dit artikel heb ik de verontwaardigde reactie vermeld op de voorgenomen executie van een overspelig stel in het huidige Iran. De vraag is nu hoe wij heden ten dage binnen onze moderne of postmoderne cultuur omgaan met de straffe regels in bijbelse teksten over overspel. Wat is hun actuele relevantie en in hoeverre zijn ze irrelevant geworden?

Bij de beantwoording van deze vraag kies ik mijn vertrekpunt bij de concrete procedures uit Deuteronomium. Wij storen ons gemakkelijk aan het gegeven dat de regelgeving zo eenzijdig gefixeerd is op de belangen van mannen en bijna helemaal voorbijgaat aan wat vrouwen denken, willen of voelen. Pressler (1994:103) velt een hard oordeel: "An examination of the Deuteronomic laws treating forcible violation of women leads to a sobering conclusion: these texts do what rape does. They eliminate women's will from consideration and erase women's right to sexual integrity." Ik geef hiervan twee voorbeelden: een meisje dat het slachtoffer is van een verkrachting, moet trouwen met de dader van dat misdrijf en deze verbintenis moet in stand blijven zolang hij leeft (Deut 22:28-29); een vrouw moet levenslang onder één dak wonen met een man die haar al na de eerste huwelijksnacht in opspraak heeft gebracht door lasterlijke verhalen te verspreiden over haar vroegere seksleven (Deut 22:19). Dergelijke regels zijn sterk bepaald zijn door de 
toenmalige samenleving en cultuur en hebben een afstotende werking op hedendaagse lezers en lezeressen.

Omgekeerd moeten we ervoor oppassen dat we onze hedendaagse westerse concepten van seksualiteit niet terugprojecteren op teksten uit de Bijbel en ons onvoldoende rekenschap geven van de betekenis en functie van deze teksten binnen hun eigen culturele setting. ${ }^{5}$

Bij een beoordeling van de relevantie of irrelevantie van bijbelse teksten over overspel moeten we kritisch ingaan op de concepten en waarden die ten grondslag liggen aan de in de teksten genoemde concrete procedures. Dan stoten we op fundamentele opties zoals:

- $\quad$ de gelijkwaardigheid versus de ongelijkwaardigheid van man en vrouw;

- $\quad$ de mannelijke zeggenschap over vrouwelijke seksualiteit versus de eigen verantwoordelijkheid van de vrouw voor haar eigen seksualiteit;

- $\quad$ het idee dat een huwelijkse verbintenis niet alleen een relatie is tussen twee personen maar ook de gemeenschap als geheel regardeert;

- het verschijnsel dat seksualiteit verbonden is met het insluiten en het uitsluiten van andere groepen.

Binnen onze hedendaagse culturele setting zijn wij bijzonder gevoelig voor de gelijkwaardigheid van man en vrouw, en voor de eigen verantwoordelijkheid van de vrouw voor haar eigen seksualiteit, terwijl in de culturen waarin de bijbelse geschriften zijn ontstaan, veelal andere concepten en normen de boventoon voerden. Daar staat tegenover dat wij huwelijk en seksualiteit sterk privatiseren en ze niet of nauwelijks weten te verbinden met de wijdere gemeenschappen waarin wij verkeren, terwijl bijbelse teksten vaak een voor ons leerzame sensitiviteit aan de dag leggen voor het gegeven dat het verkeer tussen de seksen gerelateerd is aan het wel en wee van de totale gemeenschap.

In deze bijdrage lag de nadruk op het gebruik van geweld bij het afstraffen van overspel. De Bijbel schrikt in dit geval niet terug voor de zwaarste sanctie, namelijk de doodstraf; in Deuteronomium wordt deze sanctie verder gespecificeerd: het betreft dood door openbare steniging, en dat is een van de schandelijkste en pijnlijkste vormen van executie (op dit punt vergelijkbaar met de later door de Romeinen ingevoerde kruisiging). Uit onze analyse is gebleken dat deze zware sanctie reeds in het Oude Testament zelf omgeven is door aanvullende regels die moeten voorkomen dat de doodstraf wordt uitgevoerd na een onzorgvuldige procesgang. Dit

\footnotetext{
${ }^{5}$ Een voorbeeld van een studie die onvoldoende recht doet aan de eigen culturele setting van Joh 7:53-8:11 is naar mijn oordeel Guardiola-Sáenz (2000).
} 
proces is niet pas ingezet door Jezus. De door de thora voorgeschreven waarborgen voor een zuiver proces hebben nog niet aan relevantie ingeboet.

Ten slotte nog enkele opmerkingen over de relevantie van het verhaal uit Johannes 7:53-8:11. Dit verhaal biedt aanzetten voor een decriminalisering van overspel of echtbreuk en vestigt de aandacht op de onschatbare waarde van barmhartigheid en vergeving. Hoewel in de tekst niet expliciet vermeld staat dat Jezus de vrouw vergeeft, is dit wel geïmpliceerd in het feit dat Jezus haar op vrije voeten stelt terwijl hij toch van mening is dat ze wel degelijk gezondigd heeft. We kunnen dit laatste ook als volgt uitdrukken: dit verhaal ontregelt conventionele concepten van eer en schande. De schriftgeleerden en Farizeeën claimen voor zichzelf dat ze binnen de gemeenschap recht hebben op prestige en respect; ze zijn van oordeel dat de vrouw geen respect meer verdient omdat ze zich door overspel te plegen schandelijk heeft gedragen. Jezus doorbreekt deze zwart-wit tegenstelling, enerzijds door het respect dat de opponenten voor zichzelf opeisen, te relativeren (geen van hen is zonder zonde), en anderzijds door de vrouw, die haar eer op het spel heeft gezet, in ere te herstellen en haar een nieuwe kans te geven (Neyrey 1998:15; Vosman 2005:136-154).

\section{Geciteerde literatuur}

Abu-Zahra, N 2001. s v Adultery and fornication. Encyclopaedia of the Qur'an, vol 1, 28-30.

Aus, R D 1998. "Caught in the act," walking on the sea, and the release of Barabbas revisited. Atlanta, GA: Scholars Press. (South Florida Studies in the History of Judaism 157.)

Becker, U 1963. Jesus und die Ehebrecherin: Untersuchungen zur Text- und Überlieferungsgeschichte von Joh 7:53-8:11. Berlin: Verlag Alfred Töpelmann. (BZNW 28.)

Brenner, A (ed) 1994. A feminist companion to Exodus and Deuteronomy. Sheffield: Sheffield Academic Press. (The Sheffield companion to the Bible 6.)

Claes, P 1988. Echo's echo's: De kunst van de allusie. Amsterdam: De Bezige Bij.

Delsman, W C u a (Hrsg) 1982. Von Kanaan bis Kerala: Festschrift für J P M van der Ploeg. Neukirchen-Vluyn: Neukirchener Verlag.

Derrett, J D M 1975. Law in the New Testament. London: Darton, Logman \& Todd.

Ehrman, B D 1988. Jesus and the adulteress. NTS 34, 24-44.

Frolov, D V 2006. s v Stoning. Encyclopaedia of the Qur'an, vol 5, 129-130.

Fuchs, E 2000. Sexual politics in the biblical narrative: Reading the Bible as a woman. Sheffield: Sheffield Academic Press. (JSOT Sup 310.)

Guardiola-Sáenz, L A 2000. Border-crossing and its redemptive power in John 7:538:11: A cultural reading of Jesus and the accused, in Kitzberger, I R (ed), Transformative encounters: Jesus and women re-viewed, 267-291. Leiden: Brill. (Biblical Interpretation Series 43.)

Goodfriend, E A 1992. s v Adultery. The Anchor Bible Dictionary, vol 1, 82-86. 
Heil, J P 1991. The story of Jesus and the adulteress (John 7:53-8:11) reconsidered. Bib 72, 182-191.

Holmes, B A \& Holmes Winfield, S R 2003. Sex, stones, and power games: A woman caught at the intersection of law and religion (John 7:53-8:11), in KirkDuggan, C A (ed), Pregnant passion: Gender, sex, and violence in the Bible, 143-162. Atlanta, GA: Society of Biblical Literature. (SBL Semeia Studies 44.) James, S A 1979. The adulteress and the death penalty. JETS 22, 45-53.

Kim, J K 2004. Woman and nation: An intercontextual reading of the Gospel of John from a postcolonial feminist perspective. Boston, MA: Brill.

Kirk-Duggan, C A (ed) 2003. Pregnant passion: Gender, sex, and violence in the Bible. Atlanta, GA: Society of Biblical Literature. (SBL Semeia Studies 44.)

Kitzberger, I R (ed) 2000. Transformative encounters: Jesus and women re-viewed. Leiden: Brill. (Biblical Interpretation Series 43.)

Kole, J \& De Kruijf, G (red) 2005. Het ongemak van religie: Multiculturaliteit en ethiek. Kampen: Kok.

Lührmann, D 1990. Die Geschichte von einer Sünderin und andere apokryphe Jesusüberlieferungen bei Didymos von Alexandrien. NT 32, 289-316.

Metzger, B M 1975. A textual commentary on the Greek New Testament. London: United Bible Societies.

Neyrey, J H 1998. Honor and shame in the Gospel of Matthew. Louisville, KY: Westminster John Knox.

Pessler, C 1993. The view of women found in the Deuteronomic family laws. Berlin: Walter de Gruyter. (BZAW 216.)

Pressler, C 1994. Sexual violence and Deuteronomic law, in Brenner, A (ed), $A$ feminist companion to Exodus and Deuteronomy, 102-112. Sheffield: Sheffield Academic Press. (The Sheffield Companion to the Bible 6.)

Rius-Camps, J 2007. The pericope of the adulteress reconsidered: The nomadic misfortunes of a bold pericope. NTS 53, 379-405.

Rousseau, F 1978. La femme adultère: Structure de Jn 7:53-8:11. Bib 59, 463-480.

Schwarz, O 1982. Jer 17:13 als mögliche alttestamentlicher Hintergrund zu Jo 8:6-8, in Delsman, W C u a (Hrsg), Von Kanaan bis Kerala: Festschrift für J P M van der Ploeg, 239-256. Neukirchen-Vluyn: Neukirchener Verlag.

Van Houwelingen, P H R 2007. Johannes: Het evangelie van het Woord. $3^{e}$ druk. Kampen: Kok. (Commentaar op het Nieuwe Testament.)

Vosman, F 2005. De rehabilitatie van de eer, in Kole, J \& De Kruijf, G, Het ongemak van religie: Multiculturaliteit en ethiek, 136-154. Kampen: Kok.

Watson, A 1999. Jesus and the adulteress. Bib 80, 100-108.

Weren, W J C 1999. Windows on Jesus: Methods in Gospel exegesis. London: SCM. Westbrook, R 1992. s v Punishments and crimes. The Anchor Bible Dictionary, vol 5, 546-556. 